\title{
William Butler Yeats: The Hidden Nationalism
}

\author{
Amal Riyadh Kitishat \\ Department of English Language and Literature, Ajloun University College, Al Balqa’ Applied University, Ajloun, \\ Jordan
}

\begin{abstract}
W.B. Yeats the famous Anglo Irish poet and dramatist was accused of a lack of sense of nationalism. His achievements in the reviving of the Irish culture as a means to establish a dependent Irish identity was regarded with suspicions simply due to his being a descendant of Anglo -Irish origins.In this light, the study comes to shed light on Yeats' tremendous achievements concerning his sense of nationalism and his role in the reviving Irish culture. Also, the study aims at refuting the charges against Yeats which considered him as a representative of the colonizer's class. Finally, the study proved that Yeats revealed a mature vision of nationalism which most of his contemporaries failed to notice since they only focused on one aspect of Irish identity and neglected the other; in discussing the Irish question, they were either politicians or culturalists. Whereas Yeats shows a higher degree of awareness as he believed that establishment of an identical distinctive Irish identity must be done with having both the cultural and the national elements united in one word that is "Irishness." His national creed is rooted in a kind of cohesion between culture and nationalism. It is this conclusion that not only refuted the charges againstYeats' nationalism but also put him in a position superior to any other Irish Nationalists.
\end{abstract}

Index Terms - W. B. Yeats, modern Irish drama, modern theatre, national identity, postcolonial literature

\section{INTRODUCTION}

William Butler Yeats (1865-1939) is recognized today as one of the most significant literary figures in the twentieth century. Many critics deal with him as a distinctive Irish writer,for instance Kitishat (2012) refers Yeats' importance to his efforts "in the national employment of literature for national purposes were the fountainhead by which he was able to present the national cause of his country."(p. 83) Many critics deal with him as a writer who "bears a very special relation to a particular culture." (Brooks, 1978,p. 44). Though Yeats is considered the key figure in the re-making of the Irish identity, still subsequent critics deal with his works suspiciously, politicians also degraded his national efforts. Because of his hybrid Anglo-Irish origins, he has seen a representative of the English hostile stereotype of Irish identity. Many Irish Nationalists did not believe in his nationalism simply because he is from an Anglo-Irish class and thus they identified him as reporting the English stereotype. About this point, Louro indicates that Yeats' plays were "attacked for not serving well enough the nationalist cause." (1991, p. 2382). Being a descendant of Anglo-Irish stock, Yeats was accused of disloyalty to Ireland, because he did not show much nationalism. Many critics undermined Yeats' efforts accusing him of belonging to a "colonial class," a representation of English occupation. For instance; John S. Kelly in "The Fifth Bell," argues that "after some attempts to identify with the people, [Yeats] fell back into colonial and authoritarian attitudes".(1989,p. 110)

\section{Yeats Between NATIONALism AND CULturalism}

Subsequent critics supplement the suspicious attitude toward Yeats; Kiberd for instance in Inventing Ireland argues that Yeats was working from "a version of a version" (1996,p.137), which means that he introduces a "romantic English" vision of the Irish life: English rather than Irish. Still, some critics believe that Yeats embodies a "national" rather than mere "Provincial- Culturalism," for the latter is an embodiment of the English colonized perspective of Ireland as a "province" of England. This "Provincial" view of the Irish literature undermines its importance; and thus Irish writers, including Yeats, rejected this exclusive colonized attitude toward their literature as being secondary or "disposed culture"(Brooks, p. 44).

Moreover, Yeats' hybrid origins caused him much trouble since he did not match with all the main categories that were listed of the "Irish national being." For example, in Synge and Anglo-Irish-Literature, three forces were introduced to identify the Irish national literature: they are best summarized in the following headlines; "the Religious consciousness[...], Irish Nationalism, the Land." (Brown, 1988, p. 83). In this light, being of an Anglo-Irish Protestant Ascendancy, Yeats though "a major voice," did not truly speak for "Irish reality," he "stands for the Irish tradition as broken." (Brown, 1988, p. 83)

Though Yeats attempts to refute these charges, still as Donna Gerstenberger in "W.B. Yeats: Politics and History" points out that the debate over Yeats' nationalism continued "unsettled, unsettling, and unsatisfying"(p. 81). The main charge directed to Yeats is his hybrid stock. Regarding this point Gerstenberger comments:

Yeats stood on the margins between two centuries; culturally, he belonged to neither of the classes

he admired most, peasant or nobleman, his life divided him between England and Ireland; his 
literary precursors were Shakespeare, Shelly, and Blake, although he wished to create a voice for Ireland, and, Protestant in a Catholic country.(1989, p. 86)

Another charge directed to Yeats is his "Anglo-Irish elitism" (Brown, 84). By elitism, Yeats is described as alien to the majority of the Irish people. Critics suggest that by being a representative of elitism, Yeats made a great distance between him and "the rough digestion of a crofter, a Connemara fisherman, a country shopkeeper, a country doctor, a lawyer, a policeman, a soldier." (Brown, p. 80) In other words, Yeats was accused of being cut off and isolated from the middle-class Irish people. Also, other critics accused Yeats of inauthenticity because of Yeats' tendency to idealize Irish life as mythic which means that he detached Irish people from reality.

Yeats identified himself with the Irish culture as a fountainhead of the Irish identity; he wished to transcend this identity dilemma by having a refuge in some quiet place that has nothing to do with the political disorder in his country. This refuge was found in a literary form, the Irish Celtic material in its cultural and national forms.

Yeats' efforts were mainly distorted and suspected on the grounds of "political affiliation or religion," a fact which only revealed "insularity" which Yeats often "railed" against. (Donoghue, p. 11). Not only did Yeats reject this insularity against the Anglo-Irish Ascendancy, but he also participated in many national movements such as the establishment of the Irish National Theatre, the participation in the Gaelic league as well as his literary activities. Nevertheless, even these national endeavors on Yeats' behalf were attacked by the nationalists. However, Yeats prefers to identify himself with the Irish people and rejects the English identity. Besides, he recognized that the only way to define the Irish identity is by "contrasting it with English influences" (Kelly,1989, p.117).

As for Yeats, his Anglo-Irish roots did not influence his sense of nationalism; on the contrary, he identifies himself with the Irish identity, and believes that "the Anglo-Irish tradition, mainly Protestant and aristocratic, was capacious enough to include 'old fathers' ... his own family, and the Pollex fens". (Donoghue, 55) Thus, in this light, Yeats is seen as a national as well as a cultural innovator who attempted to "educate the Irish out of provincialism and sectarianism," to "rediscover, through the agency of art, their true national character." (Deane, 1989, p.50)

No doubt that many nationalists and politicians misunderstood Yeats' efforts in reviving the Irish culture, Kiberd classifies Yeats' enemies into three main categories: Cultural conservatives, extreme Catholics, and the extremist politicians. (p. 161)

In re-staging the past, Yeats aimed to examine the cultural context of the Irish literature as a source of his themes. R. Jude Meche comments on the "re-staging of Ireland's past" is achieved, "by examining the thematic and formal experimentations" and by "trouble[ing]," Irish history .(2002,p.2882) Thus in his depiction of Irishness on the Irish theatre, Yeats develops a trend of "aesthetic resistance" to the political propaganda that some writers introduced in their works . However, Irish cultural nationalism was greatly influenced by the political change that takes place in Ireland especially that which resulted in the break of the union with England in December 1921 (Cullingford, 1984, p.109). Still, such a historical background should be taken into considerations if we tackle Yeats' sense of nationalism and his identity crisis. So, Yeats asserted the need of a distinctive national identity that differentiated the Irish theatre from his English counterparts.

Taking into consideration Yeats' Anglo-Irish stock, Yeats encountered a great enmity from some nationalists who accused him of anti-nationalism and attributed his refusal to employ his literature as a political weapon to his hybrid origins. Though Yeats was hybrid, he was loyal to Ireland and chose to identify himself with the Irish nation and to defend its national identity as distinct from that of the English.

\section{YeAts’ HybRID IDENTITY AND THE SENSE OF NATIONALISM}

Taking into consideration the cultural milieu of Anglo-Ireland, the conflict between the Anglo-Irish cultural, as well as national awareness encouraged the Irish people in their struggle against English colonization. Belonging to AngloIrish origins, Yeats introduced the modern Irish context in the light of this hybridism. The hybrid identity (Anglo-Irish) stimulates Yeats to prove how the two cultures are integrated into one. This fact justifies Yeats' restless quest for identity that had its roots in the Irish culture. However, at the same time, Yeats expresses his intentions to refine this culture so that it can play a significant role to fulfill its goals. Instead of making his works have a "cultural authority," as Taylor states, Yeats insists that theatre must have an "ethnic" quality by focussing on the spiritual or the hidden worlds which are found in Celtic Ireland.(Taylor, 1984, p.6) Ireland, with its Anglo-Irish conflicts, presents two slices in the society: the majority of the Irish people who descended from real Irish roots, and a small slice of the Irish society of hybrid origins the so-called Anglo-Irish. Concerning this point, Homes Bhabha, argues that because the colonizer had power over the colonized, he practiced many forms of discriminations which were manifested as binary opposites: the colonizer and the colonized; or in other words between the self and the other. (The Location of Culture,p.p. 34). About this point, Ashcroft et al., in Post-Colonial Studies Reader, questions the possibility of having a true cultural identity if there is a colonial authority (1995,p.2).

Accordingly, Yeats rejects the theories of colonial literature especially those concerning "the superiority" and "the rightness" of the colonial power and the portrayal of the distorted "stereotypes" of the colonized nation. (Boehmer, 3). Therefore, the Irish theatre aims to "interrogate the hegemony underlying imperial representation" which was widely spread within Irish drama. (Richards, p. 613). Thus, the Anglo-Irish identity crisis is relevant to the experience of decolonization. For instance, Shaun Richards examines the ideology of the Irish dramatists during the Revival. He 
states that "their concern was with a fundamentally "nationalist' reading of Ireland." (Shaun Richards, 616)For instance, Victor Merriman in "Besides the Obvious: Post Colonial Criticism, Drama, and Civil Society define postcolonialism as a representation of, an awareness which took place when the colonized nations resist and fight to have their rights. (p.625). In other words, postcolonial writers try to cut any contact with any theory that supports colonization. They "sought to undercut thematically and formally the discourses which supported[ ... ] the myths of power, the race classification, the imagery of subordination." (Boehmer, p. 3) Thus, W.B. Yeats is embedded under the category of postcolonial writers. Indeed, he attempts to present the Irish culture and heritage in contrast with the process of the colonizing of his country on the one hand, and at the same time a process aiming at arousing the Irish people to obtain independence from their English colonizers.

In light of post-colonial criticism, there is a great responsibility which is laid on the shoulders of the liberation movements, literature, political and cultural activities. Without the doubt, the self-realization of the Irish people as a nation is different from the English in culture as well as in language. This self-realization helped in explaining the spread of the spirit of nationalism among the Irish people. Concerning this point, Neil Lazarus in "National Consciousness and the Specificity of (Post) Colonial Intellectualism" highlights the relationship between the spread of nationalism and its contemporary theories since they play a great role in the spread of the "decolonizing project." (1994, p. 198)].

Yeats is classified under the class of national poets in whose poetry there is a national quest for occupied nations to resist occupation. For instance, Edward Said draws an analogy of Yeats' national poems with resistance poetry; he attempts to prove that Yeats was responding to certain historical moments in the history of Ireland such as the bloody events of Easter 1916 or the so-called Easter Uprising. Highlighting Yeats' efforts in this aspect, Said states that Yeats is a representative of poets who resisted imperialism, but his way was not by making poetry direct political propaganda, rather by introducing a "new narrative" for the Irish people. (1990, p. 85) What is worth mentioning in this context is Said's estimation of Yeats' effort as a nationalist represented in his efforts of decolonization. For Said, the historical and political milieu is considered as a magnificent opportunity that inspired Yeats to introduce new themes of heroism and sacrifice for his works both poetry and drama. (1990, pp. 86-7).

Yeats links the literary and imaginative freedom with his sense of nationalism. He was seeking reconciliation between "nationalism and liberty, but where he could not, chose liberty."(Cullingford, 1984, 13) Also, in Autobiographies, Yeats attacks his Irish contemporaries who degraded his nationalism. He argues that any literary work that was deliberately written for praising a political figure or event is of a low artistic value, a fact that cannot be understood but only by those who know the boundaries between the politician and the nationalist. He even claims that such literature would enslave the nation "in the name of liberty." 247)

Thus, Yeats' insistence on the compulsion of the free will even in his adoption of political or national attitudes. However, this desire to link the national and cultural without sacrificing any of them placed a heavy burden on Yeats and thus encouraged some critics to accuse him of not being national as he claimed. Taking this fact into consideration, Yeats' sense of nationalism was mistakenly considered, as the study attempts to prove, Yeats, insisted on the sovereignty of literature and the free well of people in general and writers in particular. As an Irish citizen who was deeply interested in liberating Ireland, Yeats was against the hypocrisy and materialism of the colonial state and the influence of the materialistic theories such as Communism, Socialism and thus he searched a refuge in spiritualism and mysticism which he found rooted in the Irish culture. Although Yeats is a national Irishman, he refused to allow any ideology to make him its spokesman by using his poetry as a medium for any party. Refusing this issue completely, Yeats in Autobiographies states that one of his best friends, Morris, asked him to write about Socialism and to link it to the Irish question, but he refused Morris's request saying that this was not his concern as a writer. (249)

Pondering on Yeats' interest in cultural nationalism, it must be acknowledged that Yeats as a famous Irish writer cannot be studied in isolation of the political, cultural as well as the literary movements in his age. He is a writer who was able to express his country's political culture, religious problems without any prejudice to a special part in the conflict. Yeats' great sense of responsibility made him involved in the political, cultural dilemma of asserting an identity for his people. To achieve this goal, Yeats bore in mind the audience who read his poems or watched his plays. He understood well that if the audience were aware of this national quest, his efforts would not end in vain.

Having the audience in mind, Yeats expressed his desire to win the majority of the people to his side. In Essays and Introductions, Yeats felt a great responsibility regarding his work as an Irish writer; he aims to have the attention of the simple Irish audience who was his primary concern. He believed them to be "the right audience could one but get its ears." (265)

Of the paradoxes to win the audience or to lose them, Yeats sometimes was frustrated by the failure of his Irish audience to understand his intentions, for instance in Autobiographies Yeats wrote "The Irish people were not educated enough to accept images more profound, more true to human nature, than the schoolboy thought of young Ireland." P.494)

Within this context, it is worth pointing out Yeats' national attitudes as a writer he attempted to portray his reaction regarding any incident that influenced him or affected his life regardless of its being political or not. In Essays and Introductions, Yeats expresses his attitude toward the employment of literature for political or moral purposes. He expresses his refusal because he belonged to an "a school of writers," who repudiated "to preach a doctrine to consider 
the seeming necessities of a cause." (pp. 256-57)

Regarding Yeats' refusal to adopt a specific political ideology, C.K. Stead clarifies this point saying: "He had always advanced the arguments of the nineties [1890s] to resist pressure from the Irish patriots[...] who were often puzzled by his refusal to use poetry as a political weapon." $(1977,21)$ No doubt, for Yeats there is a big difference between being a nationalist, but not a politician. Yeats writes:

All day I'd looked in the face

What I had hoped would be

To write for my race. (Yeats, The Fisherman, p.69)

However, Yeats did not see himself a politician. However, Yeats drew a line for himself not to go beyond, he is, without doubt, a patriotic and a national figure, but as clearly seen, he refused to support a party or a "government," since he is against making literature propaganda. Still, Yeats refused to be a spokesman for anyone except himself and the Irish people, as he expressed it in "The fisherman" " to write for my own race/ And the reality" (Larrissy, Yeats: A Critical Edition of the Major Works, p.68) Evidently, Yeats' importance is not only literary, it is, as Foster argues, a "diplomatic". He states that Yeats' "historical task was not militancy at home, but diplomacy abroad." (Larrissy, p. 324)

Revealing a high degree of awareness of the Irish critical historical and cultural situation, Yeats sought an active role for literature in strengthening the national feelings.Furthermore, Yeats expressed his love for Ireland and his pride in his belonging to this Gaelic culture. On Yeats' dedication to his country as he considered "love of country " and love of the "unseen life" related and inseparable. In other words, Yeats attempted through the medium of literature to "weave them together into a complete philosophy" (38). Yeats expresses this love in "I am of Ireland."

In W.B. Yeats: A Critical Edition of The Major Works. Yeats boasts:

"I am of Ireland,

And the Holy Land of Ireland

And time runs, cried she

Come out of charity:

Come dance with me in Ireland." (Yeats, I am of Ireland, p. 142).

Finally, Yeats' efforts for his country are numerous and highly estimated, he is seen as diplomatic who succeeded in shedding light on the Irish question and asserted the Irish identity while politicians (Republicans \&Unionists) failed. For this fact, the new Free State government afforded Yeats a seat in the Irish Senate in 1922. (Mac Lammoir,p. 97) Besides he was afforded the Noble Prize in 1923 for "he is remembered as an important cultural leader," also as a major "playwright."(97) In this light, Yeats' efforts are concluded to be a comprehensive approach to the establishment of the Irish identity that is rooted in national, cultural as well as aesthetic principles.

\section{CONCLUSION}

In conclusion, Yeats has a great responsibility for embodying the hopes, expectations, of the Irish people in his works. Thus, Yeats' efforts in the establishment of the Dramatic Irish movement are seen as a counterattack by which he was able to refute the charges attributed to him because of his hybrid (Anglo-Irish) origins.

By presenting plays that encouraged the Irish to have their freedom by committing themselves firmly to their cultural roots, Yeats had done a great national service for his country's quest for establishing their own national identity. Unfortunately, very few people realized his national efforts. His national philosophy was not direct political propaganda.An attitude which he firmly rejected for he believed that literature is not the place for politics. However; he made it clear that there is a vast difference between to be a politician or a nationalist. When he had the chance to choose, he chose to be a nationalist; but not a politician.

To sum up, the study proved that Yeats revealed a high degree of awareness regarding cultural identity as coupled with the nationalism.By focusing on his role in the reviving of the Irish culture in his works, Yeats was able to arouse the national identity. Yeats believed that both culture and nationalism are interrelated and cannot be separated from each other; the existence of one of them requires the existence of the other. By reaching this conclusion, the study proved that Yeats revealed a mature vision of nationalism which most of his contemporaries failed to notice since they only focused on one aspect and neglected the other; they were either politicians or culturalists. However, concerning Yeats, he was wise and smart enough to reach this cohesion between culture and nationalism. A fact which raised him over other Irish Nationalist, who always considered Yeats' sense of nationalism with suspicions because as they were blind to see his peculiar, distinctive hidden nationalism.

\section{REFERENCES}

[1] Ashcroft, et al. (1955). The Post- Colonial Studies. London: Routledge.

[2] Bhabha, Homi. (1995). The Location of Culture. New York: Routledge.

[3] Brooks, Cleanth. (1978). The Hidden God. London: Yale University.

[4] Brown, Terence. (1988). Yeats, Joyce and the Irish Critical Debate. Ireland's Literature: Selected Essays. Totowa, N.J.: Barnes \& Noble Books, pp.77-91.

[5] Cullingford, Elizabeth. (1984). Yeats, Ireland, and Fascism. London: Macmillan.

[6] Curtis, Richard Scott. (1991). Aesthetic Politics: Nietzsche and the Political Text of Yeast Poetry. DAI .vol.53, O3A. 
[7] Donoghue, Denis. (1986). We Irish: Essays on Irish Literature and Society. Brighton: The Harvester Press.

[8] Gerstenberger, Donna. (1988). W.B. Yeats Politics and History. Irish Writers and Politics. Ed. C. Komesu \& Skein Colin Smythe: Gerrards Cross, pp. 80-108.

[9] Gregory, Isabella Augusta. (1973). Our Irish Theatre. Gerrards Cross: Colin Smythe.

[10] Grene, Nicholas. (2000). Politics of Irish Drama: Plays in Context From Boucicault to Friel. Port Chester, NY, USA: Cambridge University Press.

[11] Kelly, John S. (1989). The Fifth Bell: Race and Class in Yeats's Political Thought. Irish Writers and Politics. Ed Komesu and Skein. Colin Smythe: Gerrards Cross, pp. 109-175.

[12] Kiberd, Declan. (1996). Inventing Ireland. London: Jonathan Cape.

[13] Kitishat, Amal Riyadh. (2012). Colonialism and the Recreation of Identity: The Irish Theatre as a Case Study." Journal of Language and Culture. Vol. 3(5). Pp. 83-86.

[14] Larrissy, Edward (ed). (1997). W.B. Yeats: A Critical Edition of The Major Works. New York: Oxford UP.

[15] Lazarus, Neil. (1994). National Consciousness and the Specificity of (post) Colonial Intellectualism. Colonial Discourse/postColonial Theory ed. (ED) Francis Barker (et al.). Manchester: Manchester U.P. 1.

[16] Louro, Maria Rodriguez. (1991). The Drama of J.M. Synge: A Challenge to the Ideology and Myths of Irishness.DAI. Vol.53 (1991) 07A.

[17] Mc Liammoir, Michael and Evan Boland. (1950). Theatre in Ireland. Dublin: Colin O'Lochainn.

[18] Meche, Jude R. (2002). Re-Staging the Past: Contemporary Irish Drama and The Question of history (Northern Ireland). DAI. Vol.63 (2002) 08A.

[19] Merriman, Victor. (1999). Decolonization Postponed: The Theatre of Tiger Trash.Irish University Review. (Autumn / Winter) : 305-17.

[20] Richards, Shaun. (2004). Throwing Theory at Ireland? The Field Day Theatre Company and Postcolonial Theatre Criticism." Modern Drama, 47.4 (Winter): 607-23.

[21] Said, Edward. (1992). Yeats and Decolonization. Nationalism, Colonialism, and Literature. Minneapolis: Univ. of Minnesota Press, pp. 69-95.

[22] Stead, C.K. (1975). Politics as Drama. William Butler Yeats: A Collection of Criticism. (ed.)Patrick J. Kean. London: Mc Graw Hill Book, pp. 51-55.

[23] Yeats, W.B. (1955). Autobiographies. London: Macmillan.

[24] Yeats, W.B. (1974). Essays and Introductions. London: Macmillan.

[25] Yeats, W.B. (1980). Selected Plays, Poems Criticism and Prose.( Ed). Norman Jeffares. London: Macmillan.

Amal R. Kitishat (Correspondent author), born in Salt city/The Hashemite Kingdom of Jordan in 26 of May 1970. She obtained a Ph.D. in English literature from Cairo University in 2006. She is a specialist in modern and contemporary drama.

She is an Associate Professor of English Literature, a specialist in contemporary and modern English \&Irish drama. Formerly, she held the position of Head of Department of English Language and Basic Sciences at Al Balqa Applied University \Ajloun -Jordan. Currently she is a staff member in Faculty of Arts and Head of Scientific Research Unit. Her interests in scholarship include Orientalism, English and Irish drama and literary criticism; she has published many books and articles in the field of English literary studies.

Dr. Kitishat is a member in many literary professional societies such as ALECSO - Arab League Educational, Cultural and Scientific Organization which belongs to the Arab League. Dr. Kitishat is a referee for many academic journals as well as a representative for the department of English in the Deanship of Scientific Research Unit in Faculty of Arts. 